\title{
CONTINUING EDUCATION \\ OF MUSIC ART TEACHERS IN THE PR CHINA
}

\section{Zhou Zhenyu ${ }^{1}$ Levchenko Yana ${ }^{2}$}

DOI: https://doi.org/10.30525/978-9934-571-89-3_30

Continuing education is an important part of the professionalism of any person works and teachers of music art as well. In China there are two types of teachers, who deal with music: "teachers of music" and "teachers of music art". The first type of teachers provides education in specialized schools and institutes and their students are going to be professional musicians. Mainly these teachers are or were musicians by themselves. The other type of teachers are called "music art teachers" and they work at secondary and non-specialized in music educational institutions and teach children general musical education.

The state undertakes to create conditions for the development of teachers 'own educational level and the updating of teachers' knowledge. Today, the Chinese government is actively expanding its work on retraining and deepening the knowledge of teachers in order to continuously improve the qualitative characteristics of the entire staff. For teachers of music arts who work in primary and secondary schools, continuing education courses are mainly conducted by pedagogical schools and institutes of different levels, institutes for continuing education of teachers and other retraining institutions, as well as specialized educational institutions (in the form of courses with compulsory qualification in the subject "Education")

System of continuing education of teachers is in charge for the further education of primary and secondary schools teachers, including teachers of music art, which includes centers of continuing education attached to 35 universities of the country. According to the normative documents, every teacher of music arts in particular has to undergo a continuing education course every 5 years. The course program consists of 90 hours, its passing is obligatory and on-call, for which the teacher is given a paid leave at the main place of work. The training is carried out at the accredited district consulting center (usually at a pedagogical university or an institution, occasionally in the administrations of settlements, where the corresponding specialists come from the pedagogical universities), closest to the place where the teacher works on. Completion of continuing education is payable (usually a school where the teacher works, pays expenses independently or compensates their teacher after the submission of the certificate). However, today in the PRC there is a program through which some teachers can take courses for free. The program is valid for teachers who have great success in pedagogical activities, received awards, contributed to the development of pedagogical science.

\footnotetext{
${ }^{1}$ H.S. Skovoroda Kharkiv National Pedagogical University, Ukraine

${ }^{2}$ H.S. Skovoroda Kharkiv National Pedagogical University, Ukraine
} 
Also there are the opportunities for the music art teachers as well go for the continuing education by the means of self-education, distance education, as well as by informal sector. Earlier, the improvement of the skills of teachers in China was carried out by day, evening and correspondence forms of training, but now, in the era of rapid development of information and communication technologies, the real alternative to traditional education is the distance education, where the educational process uses the best innovative means and forms, based on the latest technology.

In 1979, the University of Central Radio and Television of China was established, 1986 can be seen as the beginning of Chinese system of educational television with satellite broadcasting. By the mid-1990s China had the largest in the word system of tele- and radio education channels. Thanks to it, more than 2000 thousand teachers and directors of primary and secondary schools were given the opportunity to continue their education while remaining on their positions. Thanks to this form of training, 2310 thousand people graduated from 3 years of studying. Currently, 1100 thousand people of people annually study by radio and TV facilities in China. According to the results of self-education and distance education, a teacher may pass an examination for additional qualifications, additional competence, but the passing of the refresher courses of refresher training every 5 years remains obligatory.

China encourages leading foreign teaching staff to work with teachers both within the PRC itself and, using short- and long-term opportunities and internships with a corresponding profile of the teacher of musical art, sends its young specialists to foreign universities for the Master and Doctor of Philosophy degree. It should be noted that for the teacher of musical art, from the point of view of the People's Republic of China's Ministry of Education, the priority for obtaining a scientific degree "Master" is the specialty "Secondary education. Music". The priority for obtaining the degree of "Doctor of Philosophy" is the specialty "Professional Pedagogy" with the obligatory condition of correspondence with the subjects of study of the main specialty and the applicant`s working position.

The continuing education of a teacher and a teacher of music art in particular qualifications is the basis of the professional development. China's continuing education system is constantly improving, new methods and forms of continuous education of the teacher are presented with the full preservation of the forms traditional for the given pedagogical system. In China, modern multimedia tools are widely used, which help to simplify the process of continuing education for all categories of teachers of different specializations. The Chinese government is contributing to the improvement of continuing education system, which promotes the mobility and competitiveness of Chinese teachers, by involving foreign specialists in the system of continuing education, an online resource, and so on. However, it should be noted that the peculiarity of organizing the process of continuing education of music art teachers in the PRC today is its focus on the pedagogical component and the selectivity of the purely musical one. 


\section{References:}

1. The Reform and Development in Teacher Education in China. URL: http://www.icte.ecnu.cn/ EN/show.asp?id=547.

2. Wang Victor C. X. (2006). Instructional Strategies of Distance Education Instructors in China. The Journal of Educators Online. Vol. 3. 1. P. 1-25.

3. The PR China Law on Teachers. (2014). China. Beijing: State Commission of the People's Republic of China on education. 25 p. (in Chinese) 